\title{
Insider Trading and Informed Trading Patterns
}

G. Pyo

Konyang University, Chungnam, South Korea

\begin{abstract}
This paper aims to examine how corporate insider trading influences trading patterns of foreign and institutional investors especially in firms with high discretionary accruals and low book-to-market ratios as proxies for information uncertainty. This study uses methods such as trading patterns of informed traders who are considered to gather more precise information before and after insider trading and tests how insider trading affects informed traders. The results of this study provide evidence that insider trading is likely to influence informed traders' trading patterns. After controlling for firm-specific factors, this study finds that the event and the amount of insider trading affect significantly foreign and institutional trading patterns. Furthermore, the relation between informed trading and insider trading is more enhanced when firms have a high level of discretionary accruals and a low book-to-market ratio. Prior studies have focused on the association between abnormal returns of insider trading and types of insider information disseminated, while informed trading patterns and insider trading with information uncertainty have not been specifically considered. This study enables practitioners to interpret corporate insider trading with information uncertainty on informed trading patterns. Keywords: discretionary accruals; informed trading; insider trading
\end{abstract}

For citation: Pyo G. Insider trading and informed trading patterns. Finance: Theory and Practice. 2022;26(1):91-102. D0I: 10.26794/2587-5671-2022-26-1-91-102

ОРИГИНАЛЬНАЯ СТАТЬЯ

\section{Инсайдерская торговля и модели информированной торговли}

Университет Коньянг, Нонсан, Южный Чхунчхон, Южная Корея

\begin{abstract}
АННОТАЦИЯ
Целью данной работы является изучение влияния инсайдерской торговли на торговые модели иностранных и институциональных инвесторов, особенно в компаниях с высокими дискреционными начислениями и низким коэффициентом «книга к рынку» в качестве показателей информационной неопределенности. В данном исследовании используются такие методы, как модели торговли информированных трейдеров, которые, как считается, собирают более точную информацию до и после инсайдерской торговли, и проверяется, как инсайдерская торговля влияет на информированных трейдеров. Результаты данного исследования свидетельствуют о том, что инсайдерская торговля, вероятно, влияет на торговые модели информированных трейдеров. После контроля факторов, специфичных для конкретной фирмы, данное исследование обнаружило, что событие и объем инсайдерской торговли существенно влияют на модели торговли иностранных и институциональных трейдеров. Более того, связь между информированной и инсайдерской торговлей усиливается, когда фирмы имеют высокий уровень дискреционных начислений и низкий коэффициент «книга к рынку». Предыдущие исследования были сосредоточены на связи между аномальной доходностью инсайдерской торговли и видами распространенной информации от инсайдеров, в то время как модели информированной торговли и инсайдерской торговли в условиях информационной неопределенности специально не рассматривались. Данное исследование позволяет практикам интерпретировать корпоративную инсайдерскую торговлю с информационной неопределенностью на модели информированной торговли. Ключевые слова: дискреционные начисления; информированная торговля; инсайдерская торговля
\end{abstract}

Для цитирования: Pуо G. Insider trading and informed trading patterns. Финансы: теория и практика. 2022;26(1):91102. DOI: 10.26794/2587-5671-2022-26-1-91-102 


\section{INTRODUCTION}

Corporate insider trading is regulated in many countries. Recently financial regulators in Korea reveal new financial policies, focusing on intensified regulation of unfair trading including corporate insider trading. Following this movement, unfair trading can be strongly monitored, then insider trading may decrease, containing informative insider trading as of signaling channel of firms. As continual debating in many literature, insider trading has good and bad effects in financial markets. Prior literature report that insider trading could reduce stock demand and return rates of outsiders by information asymmetry, while insider trading could reduce investment risk by spreading out useful information of firms [1]. The informed traders are insiders [2], but this paper tries to distinguish inside informers from outside informers such as foreign traders and institutional investors. After here, this study calls informed outsiders as informed traders and informed insiders as insiders. Informed traders are regarded as experts who can scrutinize the informativeness of insider trading and collect more precise information than others [3]. Some informed traders may neglect insider trading because of unfairness or uninformativeness and are only involved in stock trading activities with informative insider signals. If so, trading patterns of informed investors are significantly related to a certain type of insider trading. On the other hand, if informed traders consider insider trading as only unfair trading, there is no evidence of the relation between insider trading and trading patterns of informed traders or there is only the opposite response of informed traders to insider trading. Thus, this study focuses on trading patterns of informed traders who are considered to gather more precise information before and after insider trading and tests how insider trading affects informed traders.

Prior research on insider trading $[1,4,5]$ reports the theoretical background and economic efficiency of insider trading. According to the empirical research of insider trading [6-8] have focused on insider trading and abnormal returns. D. Aboody and B. Lev [9] examine whether firms with R\&D investment and insider trading have more stock returns than firms with non-R\&D investment and insider trading. L. Cohen et al. [10] show that abnormal stock returns of opportunistic insider trading are greater than routine insider trading. They also report that opportunistic trading is highly occurred firms with weak governance structure. J. Lakonishok and I. Lee [11] provide evidence that insiders in smaller firms may have more information on future returns. H.N. Seyhun [2] provides evidence that shareholders have not restricted insider trading in employment contracts and do not demand additional restrictions on insider trading. If insider trading hurts the wealth of shareholders, shareholders may have desired to restrict insider trading.

H.E. Leland [1] shows analytical evidence that trading by insiders is likely to reduce investment from outsiders, assuming that outsiders only have the information of the current stock price and firms do not issue new shares. Since insiders will recognize their corporate performance precisely and participate in the stock market, outsiders will invest less in the unfair market. However, H.E. Leland [1] also shows that new and useful information will be spread out by insider trading and will reduce the investment risk of outsiders. This may influence informed traders' investment decisions more than uninformed outsiders's decisions. In the real market, institutional traders are major investors and they are considered as informed investors who are able to gather more precise information than others.

To test how insider trading influences informed traders' activities, this paper examines the change of informed trading patterns before and after insider trading. This study also utilizes the corporate information environment through the level of discretionary accruals and book-to-market ratio because it is deemed to be proxies for investment risk of stock trading. When firms experience a low book-to-market ratio and a high level of earnings management, the effect of insider trading on informed traders may be more amplified because informed traders are able to evaluate the information environment of companies. This suggests that the event, the amount, and environment of insider trading may have informativeness to informed traders.

After controlling for firm-specific factors, this study provides evidence that the event and the amount of insider trading affect foreign and institutional trading patterns. Furthermore, this study finds that the relation between informed trading and insider trading is more enhanced in firms with a high level of discretionary accruals and low book-to-market ratios.

Based on the results, this study provides further evidence for the effect of insider trading and informed trader's activities. Since informed traders are likely to reflect a bad aspect of insider trading and respond to a good aspect of insider trading, this study helps policymakers to understand corporate insider trading in firms with information uncertainty on informed trading patterns, when they face investment risk proxied by discretionary accruals and book-to-market ratios. Results in this study may help to reform insider trading regulation and apply it in the real business environment, especially in firms with a great portion of informed traders. 
The rest of this paper has five sections. The second section shows the study background and develops the hypotheses. The third section discusses the research method and the data selection procedures. The fourth section reports empirical results, and the last section concludes this study.

\section{BACKGROUND AND HYPOTHESES 2.1. Insider trading}

Empirical research on insider trading $[6,8,10]$ mainly discusses insider trading and abnormal returns, while few studies have examined informed trader and insider trading with information uncertainty. D. Aboody and B. Lev [9] examine that firms with R\&D investment and insider trading show more stock returns than firms with non-R\&D investment and insider trading. L. Cohen et al [10] show that abnormal stock returns of opportunistic insider trading are greater than routine insider trading. They report that opportunistic trading occurs in firms showing weak governance structures. J. Lakonishok and I. Lee [11] test that insiders in smaller firms may have more information of future returns.

H.E. Leland [1] provides an analytical model that insider trading is likely to reduce investment from outsiders in a certain situation that outsiders only observe the current stock price and firms do not issue new shares. Since insiders will recognize their corporate performance precisely and participate in the stock market, outsiders will invest less because of the unfairness of the capital market. Unlike prior studies, this paper employs informed trading patterns and insider trading in firms with information uncertainty, which are meaningful proxies measured as discretionary accruals and book-to-market ratio. Using these measures, this study tests the change patterns of informed traders before and after insider trading with information uncertainty.

\subsection{Information uncertainty}

S. Huddart and B. Ke [7] test corporate information environment and abnormal returns by insider trading. For measuring information environment, they use analysts' coverage, institutional trader ratios, bookto-market ratios, R\&D investment, a loss indicator, and median past abnormal returns. D. Aboody et al. [12] discuss that firms having systemic risk proxied by discretionary accruals show risk premium when insiders trade, so abnormal returns are more related to insider trading in firms with systemic risk. K.A. Rozanov [13] uses top managers' insider trading and shows that corporate governance has a tendency to determine stock price patterns by managers' insider trading. When firms have weak governance, price patterns of managers' trading increase and manager forecasts are biased. As in prior literature, this paper considers high discretionary accruals and low bookto-market ratios to control the effect for information uncertainty of firms.

As the trading patterns of informed traders after insider trading represent different aspects of insider trading, this paper examines the effect of insider trading on the trading patterns of informed traders. This study predicts that the trading patterns of informed traders are likely to be followed by informative insider trading because insider trading brings new and important information. If insider trading is not informative, insider trading may cause opposite or insignificant trading patterns by informed traders against insider trading. This argument leads to the first hypothesis in null form, as follows:

H1: Insider buying and selling are not associated with buying and selling patterns of foreign and institutional traders.

Insiders would be aware of information uncertainty in firms, so insiders in firms with information uncertainty may desire to signal their information to the market. Alternatively, insiders in firms with information uncertainty may want to behave opportunistically and exploit exclusive information to hurt outsiders. Thus, to investigate whether insider trading in firms with information uncertainty affects the trading patterns of informed investors is required. This argument leads to the second and third hypotheses.

H2: Insider buying and selling in firms with high discretionary accruals are not associated with buying and selling patterns of foreign and institutional traders.

H3: Insider buying and selling in firms with low book-to-market ratios are not associated with buying and selling patterns of foreign and institutional traders.

If the first hypotheses show a significant relation between insider trading and trading patterns of foreign and institutional traders, this study predicts that there would be an incremental effect caused by information uncertainty.

\section{RESEARCH METHOD AND DATA SELECTION}

To test how insider trading affects trading patterns of informed traders, this paper uses an indicator representing the event of insider trading, the amount of insider trading, an indicator for information uncertainty, and interaction terms among insider trading terms and information uncertainty terms. To reduce statistical noise and exclude liquidity transactions by insiders, this study chooses an 
intensive insider trading month, identifying an indicator of the event and the amount of insider trading as in J.F. Jaffe [14]. For measuring the level of a firm's information uncertainty, this paper utilizes discretionary accruals and book-to-market ratios. Both discretionary accruals and book-to-market ratios can be used as proxies for information uncertainty, enhancing investment risk [7, 12, 15].

\subsection{Earnings quality}

For the information uncertainty of corporate financial reporting, discretionary accruals are used as a proxy of earnings management. This study utilizes the modified-Jones discretionary accruals model as suggested in P. Dechow et al. [16]. For assigning firms with the high level of discretionary accruals, firms in the first quartile of the greatest discretionary accruals correspond to firms with high discretionary accruals. Since discretionary accruals are calculated by estimation errors, this paper calculates each firm's discretionary accruals through each industry and year clusters. Discretionary accruals are computed by equation (1) as used in P. Dechow et al. [16] and calculating procedures are explained in K. S. Ali et al. [17].

$$
\frac{T A_{i t}}{A_{i t-1}}=\alpha_{0} \frac{1}{A_{i t-1}}+\alpha_{1} \frac{\Delta R E V_{i t}-\Delta A R_{i t}}{A_{i t-1}}+\alpha_{2} \frac{P P E_{i t}}{A_{i t-1}}+\varepsilon_{i t},
$$

where

$\mathrm{A}=$ the total assets in year $t-1$;

$\mathrm{TA}=$ the total accruals (net income - cash flow from operations) in year $t$ for firm $i$;

$\triangle \mathrm{REV}=$ the difference between revenues in year $t$ and in year $t-1$;

$\Delta \mathrm{AR}=$ the difference between accounts receivables in year $t$ and in year $t-1$;

$\mathrm{PPE}^{1}=$ the net depreciable property, plant, and equipment in year $t$;

$\mathrm{DA}=$ discretionary accruals from the estimated residuals in model (1).

\subsection{Book-to-market ratio}

As in J. Liew and M. Vassalou [18], the book-to-market ratio is of risk factors that can explain firms' growth in the capital market and even future economic growth in some countries. This study calculates the book-tomarket ratio with firms' book value of equity in the previous insider trading. Prior studies in insider trading $[7,20]$ also consider the book-to-market ratio as an indicator for the level of the information environment of firms because a low book-to-market ratio indicates firms with high growth and information asymmetry. For identifying firms with the low level of book-to-market ratio, firms in the first quartile of the bottom bookto-market value correspond to firms with the low book-to-market ratio. For controlling the industrial and periodic effects, each firm's ratio from each industry and year clusters is calculated.

\subsection{Research model}

As in prior studies $[7,12,15]$, this study expects that insider trading and information uncertainty influence trading patterns of informed traders as in equation (2). This paper uses the following model to test the three hypotheses, and definitions of variables are in Table 4 Panel A.

$$
\begin{aligned}
& \text { For }_{i t}\left(\text { or inst }_{i t}\right)=\beta_{0}+\beta_{1} I T B U Y d_{i t}+\beta_{2} I T S E L L d_{i t}+\beta_{3} I T B U Y v_{i t}+\beta_{4} I T S E L L v_{i t}+\beta_{5} d d a_{i t} \\
& +\beta_{6} d b m_{i t}+\beta_{7} I T B U Y d_{i t} \times d d a_{i t}+\beta_{8} I T B U Y d_{i t} \times d b m_{i t}+\beta_{9} I T S E L L d_{i t} \times d d a_{i t} \\
& +\beta_{10} I T S E L L d_{i t} \times d b m_{i t}+\beta_{11} I T B U Y v_{i t} \times d d a_{i t}+\beta_{12} I T B U Y v_{i t} \times d b m_{i t} \\
& +\beta_{13} I_{T S E L L v} \times d d a_{i t}+\beta_{14} I_{T S E L L v} \times d b m_{i t}+\beta_{15} \text { priorv }_{i t}+\beta_{16} S_{I Z E_{i t}} \\
& +\beta_{17} R O A_{i t}+\beta_{18} C F O_{i t}+\beta_{19} L E V_{i t}+\beta_{20} G R W_{i t}+\sum I N D \& Y R+\varepsilon_{i t}
\end{aligned}
$$

As in prior studies [12,15,20,21], this study expects that firms with a lower book to market value, a smaller size, a higher return, a greater cash flow ratio, greater leverage, and a greater growth rate are likely to have more inside information and stronger reaction by traders.

\footnotetext{
${ }^{1}$ Consistent with J. Culvenor et al. [19]. PPE excludes land and construction in progress.
} 


\section{Sample Descriptions}

\begin{tabular}{|l|c|}
\hline \multicolumn{1}{|c|}{ Selection Criteria } & Observations \\
\hline All firm-month observations on the Korea Stock Exchange (KSE) & 46,440 \\
\hline $\begin{array}{l}\text { (Less) Firm-month observations with insufficient financial data } \\
\text { (Less) Financial service }\end{array}$ & $(7,547)$ \\
\hline (Less) Firm-month observations with consecutive insider trading month & $(4,860)$ \\
\hline (Less) Firm-month observations with negative equity & $(81)$ \\
\hline Final Sample Size & 33,908 \\
\hline
\end{tabular}

Source: built by the author based on data from KIS-VALUE, FnGuide, DART system.

Based on prior research, several control variables are added. SIZE may control the impacts by omitted variables on the investment environment [10]. J.D. Piotroski and D.T. Roulstone [15] show a positive relationship between CFO, ROA, and insider buying. LEV may capture firm's risk and informed traders reflect bad credit news in trading activities [22]. GRW is also considerable, implying that if firms with growth options, investors tend to experience information uncertainty [23].

\subsection{Data selection}

Table 1 provides the sample used in this study from 2007 to 2011. This paper excludes firm-month observations with insufficient financial data, those in financial service industries, those with the second consecutive insider trading month, and those with negative equity. Financial data are extracted from the KIS-VALUE database by NICE Information Service and Fnguide database by FnGuide Inc., and insider trading samples are obtained from DART System (Data Analysis, Retrieval and Transfer System) by Financial Supervisory Service in Korea.

\section{EMPIRICAL RESULTS 4.1. Descriptive statistics}

Table 2 reports descriptive statistics of dependent, independent, and control variables. This study winsorizes variables with continuous values at the $1 \mathrm{st}$ and the 99th percentiles to control for the effects of extreme observations. The mean value of the change ratio of the net stock buying amount of foreign investors (For_Netv) is 0.0002 , which is scaled by market value. ${ }^{2}$

\footnotetext{
${ }^{2}$ For avoiding endogeneity issue, all dependent variables, For_Netv, For_Absv, For_Buyv, For_Sellv, Inst_Netv, Inst_Absv, Inst_Buyv, and Inst_Sellv, are computed by the different ratio of trading amount between in after month and in before month of insider trading.
}

The mean value of the absolute total trading ratio (For_Absv, 0.0127) is about the sum of buying and selling ratio of foreign traders (For_Buyv and For_Sellv). Inst_Netv has the mean value around zero, and Inst Absv is the sum of the stock buying and selling ratio of institutional investors (Inst_Buyv and Inst_Sellv). While the max value of For_Netv is similar to that of Inst_Netv, the max value of For_Buyv and For_Sellv is half of Inst Buyv and Inst_Sellv. The binary variable for the event of Insider buying (ITBUYd) accounts for $1.3 \%$ of this test sample and the ratio of Insider selling dummy (ITSELLd) is about half of ITBUYd. The average amount of insider selling (ITSELLV) is around half of the insider buying amount (ITBUYv). Regarding the level of discretionary accruals and book-to-market ratios, firms with high discretionary accruals and the low book-to-market ratio at the first quartile account for about $24 \%$ of the final sample.

Table 3 shows the correlation matrix by the variables used in the empirical analyses. The highest correlation of continuous variables is 0.4921 between ROA and CFO. ${ }^{3}$ The rest of the variables are not highly correlated. The highest VIF value in the regression analyses is below 2.3 and the condition index (not tabulated) is low which infers that multicollinearity is not serious in this study. ${ }^{4}$

\subsection{Regression results}

Panel A and panel B of Table 4 represent the empirical results of multivariate regression analyses to test three hypotheses. The For_Netv model provides the relation between insider trading and the net stock buying amount of foreign investors. ITBUYv*dda is

\footnotetext{
${ }^{3}$ Dropping either ROA or CFO does not change the conclusion in this study and yields qualitatively identical results.

${ }^{4}$ For mitigating heteroscedasticity problem, this study uses heteroscedasticity-consistent estimators as in H.A. White [24]. Durbin-Watson test does not provide statistical evidence of autocorrelation in these regression models (not tabulated).
} 


\section{Descriptive Statistics}

\begin{tabular}{|c|c|c|c|c|c|c|c|}
\hline $\begin{array}{l}\text { Variables } \\
(\mathrm{N}=33,908)\end{array}$ & MEAN & STD & MIN & Q1 & Median & Q3 & MAX \\
\hline For_Netv & 0.0002 & 0.1646 & -4.7900 & -0.0233 & 0.0000 & 0.0245 & 5.1280 \\
\hline For_Absv & 0.0127 & 0.3843 & -9.5885 & -0.0511 & 0.0000 & 0.0513 & 11.7026 \\
\hline For_Buyv & 0.0064 & 0.2091 & -5.0201 & -0.0257 & 0.0000 & 0.0254 & 6.6146 \\
\hline For_Sellv & 0.0061 & 0.2092 & -4.5684 & -0.0270 & 0.0000 & 0.0290 & 5.6380 \\
\hline Inst_Netv & 0.0003 & 0.2335 & -4.8832 & -0.0301 & 0.0000 & 0.0329 & 6.1575 \\
\hline Inst_Absv & 0.0112 & 0.4407 & -7.1486 & -0.0472 & 0.0000 & 0.0418 & 20.3354 \\
\hline Inst_buyv & 0.0058 & 0.2570 & -4.3017 & -0.0246 & 0.0000 & 0.0193 & 10.9541 \\
\hline Inst_Sellv & 0.0056 & 0.2403 & -3.8191 & -0.0237 & 0.0000 & 0.0231 & 10.5338 \\
\hline ITBUYd & 0.0134 & 0.1148 & 0 & 0 & 0 & 0 & 1 \\
\hline ITSELLd & 0.0069 & 0.0826 & 0 & 0 & 0 & 0 & 1 \\
\hline ITBUYV & 0.0437 & 0.3763 & 0.0000 & 0.0000 & 0.0000 & 0.0000 & 7.1976 \\
\hline ITSELLV & 0.0220 & 0.2649 & 0.0000 & 0.0000 & 0.0000 & 0.0000 & 3.2351 \\
\hline$d d a$ & 0.2283 & 0.4198 & 0 & 0 & 0 & 0 & 1 \\
\hline$d b m$ & 0.2395 & 0.4268 & 0 & 0 & 0 & 0 & 1 \\
\hline priorv & 0.0004 & 0.2899 & -18.7932 & -0.0288 & 0.0000 & 0.0300 & 15.3744 \\
\hline SIZE & 26.5175 & 1.4959 & 23.8791 & 25.4343 & 26.2011 & 27.3520 & 30.7195 \\
\hline$R O A$ & 0.0314 & 0.0822 & -0.3907 & 0.0084 & 0.0376 & 0.0733 & 0.2136 \\
\hline CFO & 0.0447 & 0.0848 & -0.2275 & -0.0019 & 0.0440 & 0.0925 & 0.3004 \\
\hline LEV & 0.4345 & 0.1924 & 0.0431 & 0.2871 & 0.4469 & 0.5758 & 0.8945 \\
\hline GRW & 0.1121 & 0.2250 & -0.5099 & 0.0048 & 0.0799 & 0.1769 & 1.2284 \\
\hline
\end{tabular}

Source: built by the author based on data from KIS-VALUE, FnGuide, DART system.

significant and negatively associated with For_Netv at the significance of 5 percent. When insiders in firms with high discretionary accruals purchase stocks more, one of the informed traders, foreign investors, tend to avoid risk and reduce stock buying for the firm. The coefficient of ITSELLv*dda means that insiders selling also influences decreased net trading amount by foreign traders. If insider selling carries information of a firm's performance, foreign traders consider insider selling as a significant sign of firms with high discretionary accruals. Regarding ITSELLv* $\mathrm{dbm}$, the net amount by foreign traders are likely to be increased when firms have a low book-tomarket ratio and insiders sell their stocks.

When this study includes indicator variables for the event of insider trading, ITBUYd*dda and ITSELLd*dda, an intercept is increased by the event of insider trading in firms with high discretionary accruals, and the effect of the amount of insider buying and selling in firms with dda are intensified at the significant level of 1 percent.

The For Absv model shows the influence of insider trading on absolute total trading amounts by foreigners. ITBUYv ${ }^{*}$ dda has a significant coefficient as in For Netv model but ITSELLv*dda is opposite to that of For_Netv model. This may result in the difference in the dominant change ratio of buying and selling by foreign traders.

In panel B of Table 4, the test results show whether buying or selling patterns of foreign traders dominate net trading patterns or absolute total trading patterns by foreigners. The event of insider selling affects selling 
$\frac{m}{\frac{0}{0}}$

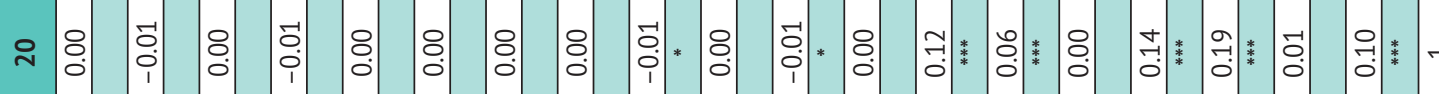

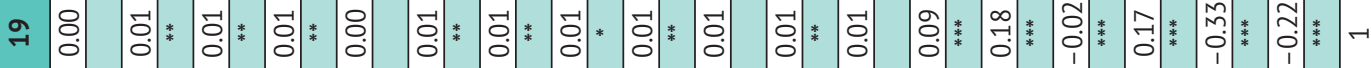

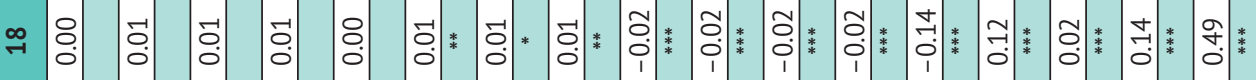

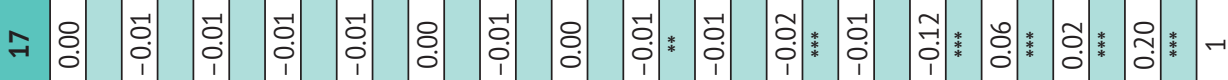

이 0

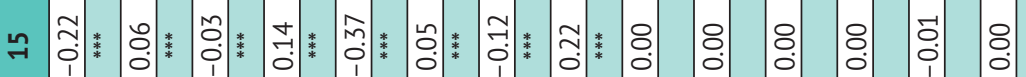

t

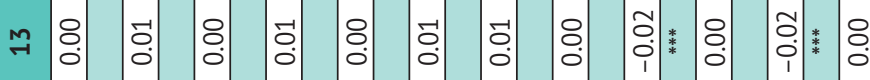

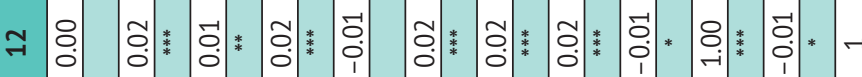

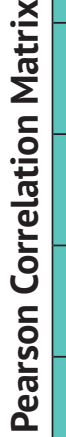

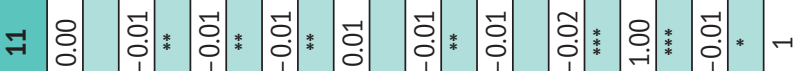

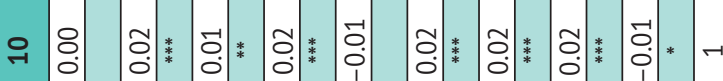

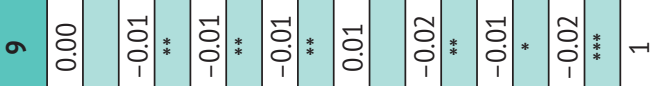

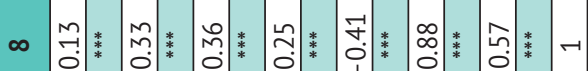

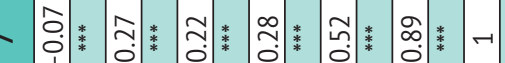

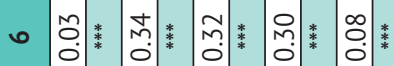

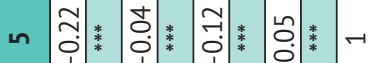

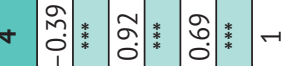

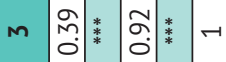

N

yํํㅇำ

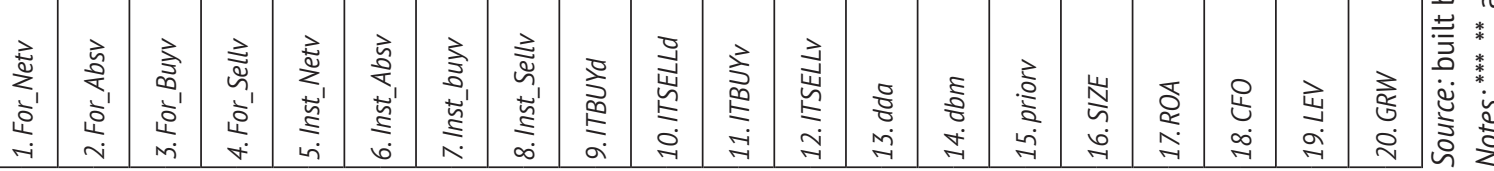




\section{Informed Traders and Insider Trading - Foreign Traders}

Panel A. Net and Absolute total Trading

\begin{tabular}{|c|c|c|c|c|c|c|c|c|c|c|c|c|}
\hline \multirow{2}{*}{$\begin{array}{c}\text { Variables } \\
(N=33,908)\end{array}$} & \multicolumn{5}{|c|}{ For_Netv } & & \multicolumn{6}{|c|}{ For_Absv } \\
\hline & Coeff. & White $t$ & & Coeff. & White $t$ & & Coeff. & White $t$ & & Coeff. & White $t$ & \\
\hline Intercept & 0.003 & 0.2 & & 0.003 & 0.2 & & 0.030 & 0.7 & & 0.031 & 0.7 & \\
\hline ITBUYd & - & - & & -0.006 & -1.0 & & - & - & & -0.029 & -1.6 & \\
\hline ITSELLd & - & - & & -0.023 & -1.0 & & - & - & & 0.095 & 2.4 & ** \\
\hline ITBUYV & -0.001 & -0.2 & & 0.001 & 0.2 & & -0.005 & -0.2 & & 0.009 & 0.4 & \\
\hline ITSELLV & -0.006 & -0.1 & & 0.015 & 0.4 & & 0.037 & 0.5 & & -0.046 & -0.7 & \\
\hline$d d a$ & 0.000 & -0.2 & & -0.001 & -0.4 & & 0.007 & 1.2 & & 0.007 & 1.2 & \\
\hline$d b m$ & -0.001 & -0.6 & & -0.001 & -0.5 & & -0.005 & -0.8 & & -0.004 & -0.8 & \\
\hline ITBUYd*dda & - & - & & 0.028 & 1.8 & ${ }^{*}$ & - & - & & 0.037 & 0.9 & \\
\hline ITBUYd*dbm & - & - & & -0.018 & -0.9 & & - & - & & -0.025 & -0.6 & \\
\hline ITSELLd*dda & - & - & & 0.075 & 2.1 & ** & - & - & & -0.066 & -1.1 & \\
\hline ITSELLd $d^{*} d b m$ & - & - & & 0.002 & 0.1 & & - & - & & -0.050 & -0.9 & \\
\hline ITBUYV $V^{*} d d a$ & -0.053 & -2.2 & ${ }^{* *}$ & -0.069 & -3.0 & ${ }^{* * *}$ & -0.283 & -3.0 & $* * *$ & -0.302 & -3.0 & $* * *$ \\
\hline$I T B U Y V^{*} d b m$ & -0.002 & -0.1 & & 0.008 & 0.7 & & -0.061 & -1.3 & & -0.050 & -1.1 & \\
\hline ITSELLV*dda & -0.129 & -2.0 & *** & -0.204 & -3.5 & ${ }^{* * *}$ & 0.228 & 2.7 & $* * *$ & 0.286 & 2.9 & $* * *$ \\
\hline ITSELLV ${ }^{*} d b m$ & 0.135 & 2.1 & ${ }^{* *}$ & 0.131 & 1.9 & ${ }^{*}$ & -0.009 & -0.1 & & 0.024 & 0.3 & \\
\hline priorv & -0.128 & -7.2 & **** & -0.127 & -7.2 & ${ }^{* * *}$ & 0.081 & 2.9 & **** & 0.081 & 2.9 & ${ }^{* * * *}$ \\
\hline SIZE & 0.000 & -0.4 & & 0.000 & -0.4 & & -0.001 & -0.4 & & -0.001 & -0.5 & \\
\hline$R O A$ & -0.008 & -0.6 & & -0.009 & -0.6 & & -0.014 & -0.3 & & -0.013 & -0.3 & \\
\hline CFO & 0.018 & 1.2 & & 0.018 & 1.2 & & 0.055 & 1.5 & & 0.055 & 1.5 & \\
\hline$\angle E V$ & -0.001 & -0.2 & & -0.001 & -0.1 & & 0.032 & 2.5 & ** & 0.032 & 2.6 & *** \\
\hline GRW & 0.001 & 0.1 & & 0.001 & 0.1 & & -0.010 & -0.9 & & -0.010 & -0.9 & \\
\hline INDNEAR & \multicolumn{2}{|c|}{ Included } & & \multicolumn{2}{|c|}{ Included } & & \multicolumn{2}{|c|}{ Included } & & \multicolumn{2}{|c|}{ Included } & \\
\hline F-value & 75.93 & $* * *$ & & 61.06 & $* * *$ & & 9.4 & *** & & 7.84 & *** & \\
\hline Adj R square & 0.050 & & & 0.051 & & & 0.006 & & & 0.006 & & \\
\hline Max VIF & 1.86 & & & 2.24 & & & 1.86 & & & 2.24 & & \\
\hline
\end{tabular}

amounts of foreigners, and this increases absolute total amounts by foreign traders. ITSELLd with dda reduces For_Sellv which increases the net buying amount of foreigners. ITBUYv with dda is likely to decrease For_Buyv and For_Sellv in the same direction which cause decline of For_Netv and For_Absv. This indicates that insider buying in firms with dda decrease For_Buyv greater than For_Sellv. These results infer that insider buying is one of committing personal capital and contribute to stop of foreigners selling even in firms with dda, while this behavior fails to promote foreigners' buying. This result is consistent with Aboody et al. (2005) which report that firms with high discretionary accruals pay more risk premium when insiders trading. Regarding ITSELLv* $\mathrm{dbm}$, the results fail to find any significant domination of For_Buyv or For_Sellv, directing an increase of For_Netv. Consistent with this study's prediction, foreign traders regard insider selling in firms with dda as an important signal for deciding selling patterns.

Table 5 shows the test results of three hypotheses for institutional traders. The Inst_Netv, net buying amount by institutional traders, are positively related to ITBUYv with dda at the significance of 1 percent. Unlike For_Netv, institutional traders prefer firms with dda when they respond to insider buying.

After including indicator variables for the event of insider trading, ITBUYd and ITSELLd, there is a significant relation between Inst_Netv and ITSELLV with dda and the effect of ITBUYv with dda are enhanced.

In the Inst_Absv model, there are more significant coefficients when indicator variables are added, the event of insider trading. Indicator variables, ITBUYd, ITSELLd, and ITBUYd*dda, influence the change of an intercept, and the amount of insider buying in firms with dda, ITBUYv*dda, decreases the absolute total trading amount of institutional investors as in For_Absv.

Panel B of Table 5 provides the test results of buying or selling patterns of institutional traders, directing net trading patterns or absolute total trading patterns by institutions. The event of insider buying and selling influences buying and selling amounts 
Panel B. Buy and Sell Trading

\begin{tabular}{|c|c|c|c|c|c|c|c|c|c|c|c|c|}
\hline \multirow{2}{*}{$\begin{array}{c}\text { Variables } \\
(N=33,908)\end{array}$} & \multicolumn{5}{|c|}{ For_Buyv } & & \multicolumn{6}{|c|}{ For_Sellv } \\
\hline & Coeff. & White $t$ & & Coeff. & White $t$ & & Coeff. & White $t$ & & Coeff. & White $t$ & \\
\hline Intercept & 0.020 & 0.9 & & 0.021 & 0.9 & & 0.017 & 0.7 & & 0.017 & 0.8 & \\
\hline ITBUYd & - & - & & -0.018 & -1.6 & & - & - & & -0.012 & -1.6 & \\
\hline ITSELLd & - & - & & 0.036 & 1.6 & & - & - & & 0.059 & 2.4 & *** \\
\hline ITBUYV & -0.004 & -0.3 & & 0.005 & 0.3 & & 0.001 & 0.1 & & 0.007 & 0.6 & \\
\hline ITSELLV & 0.017 & 0.8 & & -0.013 & -0.5 & & 0.019 & 0.4 & & -0.033 & -0.8 & \\
\hline dda & 0.003 & 1.0 & & 0.003 & 0.8 & & 0.004 & 1.3 & & 0.004 & 1.3 & \\
\hline$d b m$ & -0.003 & -1.1 & & -0.003 & -1.0 & & -0.002 & -0.5 & & -0.002 & -0.5 & \\
\hline ITBUYd*dda & - & - & & 0.031 & 1.6 & & - & - & & 0.014 & 0.6 & \\
\hline ITBUYd*dbm & - & - & & -0.020 & -0.9 & & - & - & & -0.001 & -0.1 & \\
\hline ITSELLd $d^{*} d d a$ & - & - & & -0.002 & -0.1 & & - & - & & -0.065 & -1.8 & ${ }^{*}$ \\
\hline ITSELLd $d b m$ & - & - & & -0.020 & -0.7 & & - & - & & -0.029 & -0.8 & \\
\hline ITBUYV* ${ }^{*} d a$ & -0.155 & -2.9 & $* * *$ & -0.172 & -3.1 & ${ }^{* * *}$ & -0.168 & -2.9 & $* * * *$ & -0.175 & -2.8 & $* * *$ \\
\hline ITBUYV*dbm & -0.030 & -1.2 & & -0.021 & -0.9 & & -0.039 & -1.5 & & -0.038 & -1.5 & \\
\hline ITSELLV*dda & 0.047 & 1.4 & & 0.045 & 1.2 & & 0.182 & 2.8 & $* * * *$ & 0.243 & 3.6 & $* * *$ \\
\hline ITSELLV*dbm & 0.047 & 0.9 & & 0.057 & 1.1 & & -0.063 & -1.1 & & -0.041 & -0.7 & \\
\hline priorv & -0.023 & -2.0 & ${ }^{* *}$ & -0.023 & -2.0 & $* *$ & 0.103 & 5.0 & $* * * *$ & 0.103 & 5.0 & $* * *$ \\
\hline SIZE & -0.001 & -0.7 & & -0.001 & -0.8 & & 0.000 & -0.4 & & 0.000 & -0.4 & \\
\hline$R O A$ & -0.010 & -0.4 & & -0.010 & -0.4 & & -0.003 & -0.1 & & -0.003 & -0.1 & \\
\hline CFO & 0.035 & 1.7 & ${ }^{*}$ & 0.035 & 1.7 & ${ }^{*}$ & 0.020 & 1.0 & & 0.020 & 1.0 & \\
\hline LEV & 0.016 & 2.4 & ${ }^{* *}$ & 0.016 & 2.4 & $* *$ & 0.017 & 2.4 & ${ }^{* *}$ & 0.017 & 2.4 & $* *$ \\
\hline GRW & -0.005 & -0.9 & & -0.005 & -0.9 & & -0.005 & -0.9 & & -0.005 & -0.9 & \\
\hline IND/NEAR & \multicolumn{2}{|c|}{ Included } & & \multicolumn{2}{|c|}{ Included } & & \multicolumn{2}{|c|}{ Included } & & \multicolumn{2}{|c|}{ Included } & \\
\hline F-value & 4.80 & $* * *$ & & 4.11 & $* * *$ & & 33.61 & $* * *$ & & 27.24 & $\cdots$ & \\
\hline Adj R square & 0.003 & & & 0.003 & & & 0.023 & & & 0.023 & & \\
\hline Max VIF & 1.86 & & & 2.24 & & & 1.86 & & & 2.24 & & \\
\hline
\end{tabular}

Source: built by the author based on data from KIS-VALUE, FnGuide, DART system.

Notes: ***,**, and * represent significant levels at the 1, 5, and 10 percent levels, respectively.

Definitions of variables are in Table 4 Panel A.

For_Netv indicates that the change ratio of net trading amount scaled by market value is measured by the change of net stock trading amount by foreign traders in between the previous month and the next month of insider trading. As of For_Netv, For_Absv, Inst_Netv, and Inst_Absv represent the change ratio of absolute total stock trading amount by foreign traders, net and absolute total trading amount by institutional investors, respectively. For_Buyv indicates that the change ratio of trading amount scaled by market value is measured by the change of stock purchase amount by foreign traders in between the previous month and the next month of insider trading. As of For_Netv, For_Buyv, For_Sellv, Inst_Buyv, and Inst_Sellv denote the change ratio of stock selling amount by foreign traders, stock buying and selling amount by institutional investors, respectively. ITBUYd and ITSELLd are 1 if a firm has insider buying and insider selling in each month, respectively, and 0 otherwise. ITBUYV and ITSELLV denote the natural log value of monthly insider buying and insider selling amount. $d d a$ is 1 if a firm has high discretionary accruals in the previous year and each industry and 0 otherwise. $\mathrm{dbm}$ is 1 if a firm has a low book to market value in the prior year and each industry and 0 otherwise. priorv denotes the net of foreign and institutional trading amount scaled by market value in the previous month. SIZE is the natural log of the beginning total assets. $R O A$ is net income scaled by total assets at the beginning. CFO is the operating cash flow scaled by the beginning total assets. LEV is the leverage ratio from total debt scaled by the beginning total assets. GRW denotes the beginning asset changes scaled by prior assets. IND/YEAR is dummies representing each industry and year.

of institutional traders which lead to direct absolute total amounts by institutional traders. ITBUYd with dda promotes Inst_Sellv and increases the absolute total trading amount of institutions, Inst_Absv.
ITBUYv with dda are prone to decrease Inst_Sellv, which declining Inst_Absv at the significance of 10 percent. This indicates that decreased selling of institutional investors is bigger than increased Inst_ 
Informed Traders and Insider Trading - Institutional Traders

Panel A. Net and Absolute total Trading

\begin{tabular}{|c|c|c|c|c|c|c|c|c|c|c|c|c|}
\hline \multirow{2}{*}{$\begin{array}{c}\text { Variables } \\
(N=33,908)\end{array}$} & \multicolumn{5}{|c|}{ Inst_Netv } & & \multicolumn{6}{|c|}{ Inst_Absv } \\
\hline & Coeff. & White $t$ & & Coeff. & White $t$ & & Coeff. & White $t$ & & Coeff. & White $t$ & \\
\hline Intercept & 0.003 & 0.1 & & 0.003 & 0.1 & & -0.06 & -1.3 & & -0.054 & -1.2 & \\
\hline ITBUYd & - & - & & 0.006 & 0.7 & & - & - & & -0.055 & -3.1 & **** \\
\hline ITSELLd & - & - & & 0.002 & 0.1 & & - & - & & 0.117 & 2.3 & *** \\
\hline ITBUYV & 0.001 & 0.1 & & -0.002 & -0.3 & & -0.04 & -1.8 & ${ }^{*}$ & -0.014 & -0.9 & \\
\hline ITSELLV & -0.054 & -1.2 & & -0.057 & -1.1 & & 0.07 & 0.8 & & -0.032 & -0.4 & \\
\hline$d d a$ & 0.002 & 0.5 & & 0.002 & 0.6 & & 0.01 & 1.6 & & 0.010 & 1.4 & \\
\hline$d b m$ & -0.002 & -0.6 & & -0.002 & -0.7 & & -0.01 & -1.6 & & -0.009 & -1.6 & \\
\hline ITBUYd"dda & - & - & & -0.011 & -0.5 & & - & - & & 0.061 & 2.0 & *** \\
\hline ITBUY $d^{*} d b m$ & - & - & & 0.026 & 1.2 & & - & - & & -0.038 & -1.1 & \\
\hline ITSELLd*dda & - & - & & -0.049 & -0.8 & & - & - & & 0.046 & 0.5 & \\
\hline ITSELLd*dbm & - & - & & -0.023 & -0.4 & & - & - & & 0.000 & 0.0 & \\
\hline ITBUYV $V^{*} d d a$ & 0.105 & 2.7 & $* * *$ & 0.111 & 2.6 & **** & -0.01 & -0.3 & & -0.038 & -1.8 & * \\
\hline ITBUYV* $d b m$ & 0.012 & 0.7 & & 0.000 & 0.0 & & 0.02 & 0.6 & & 0.034 & 1.4 & \\
\hline ITSELLv $v^{*} d d a$ & 0.078 & 1.4 & & 0.131 & 2.0 & $* *$ & -0.02 & -0.2 & & -0.083 & -0.7 & \\
\hline ITSELLv*dbm & -0.026 & -0.3 & & 0.012 & 0.1 & & 0.01 & 0.1 & & -0.053 & -0.4 & \\
\hline priorv & -0.295 & -6.0 & $* * *$ & -0.295 & -6.0 & ${ }^{* * *}$ & 0.07 & 2.4 & ** & 0.072 & 2.4 & *** \\
\hline SIZE & 0.000 & -0.1 & & 0.000 & -0.1 & & 0.00 & 1.2 & & 0.002 & 1.2 & \\
\hline$R O A$ & -0.009 & -0.5 & & -0.009 & -0.5 & & -0.02 & -0.4 & & -0.016 & -0.4 & \\
\hline CFO & 0.033 & 1.7 & ${ }^{*}$ & 0.033 & 1.7 & ${ }^{*}$ & 0.08 & 1.7 & ${ }^{*}$ & 0.080 & 1.7 & * \\
\hline LEV & -0.001 & -0.1 & & -0.001 & -0.1 & & 0.04 & 2.6 & *** & 0.039 & 2.6 & $* * *$ \\
\hline GRW & -0.003 & -0.4 & & -0.003 & -0.4 & & -0.02 & -1.4 & & -0.015 & -1.4 & \\
\hline INDNEAR & \multicolumn{2}{|c|}{ Included } & & \multicolumn{2}{|c|}{ Included } & & \multicolumn{2}{|c|}{ Included } & & \multicolumn{2}{|c|}{ Included } & \\
\hline F-value & 218.6 & $* * *$ & & 175.0 & $* * *$ & & 5.9 & $* * *$ & & 5.4 & *** & \\
\hline Adj R square & 0.134 & & & 0.133 & & & 0.004 & & & 0.004 & & \\
\hline Max VIF & 1.86 & & & 2.24 & & & 1.86 & & & 2.24 & & \\
\hline
\end{tabular}

Buyv. As in For_Absv model, this result infers that insider buying with dda limit to selling of institutional traders, while ITBUYv with dda increases Inst_Buyv and Inst_Netv. Following insider buying in firms with dda, institutional investors show trading patterns consistent with this study's prediction for insiders' buying signal with informativeness.

In summary, this study predicts that trading patterns of informed traders are followed by informative insider trading, and unimportant insider trading causes opposite or insignificant trading patterns by informed traders against insider trading. This paper finds that insider trading is likely to influence stock trading patterns of informed traders, institutional investors and foreign traders. This result suggests that the event and the amount of some insider trading provide informativeness to informed traders. There is further evidence that this phenomenon is more intensified when firms experience information uncertainty through low book-to-market ratios and high earnings management.

\section{CONCLUSION}

This study examines how insider trading influences the trading pattern of foreign and institutional investors. H.E. Leland [1] shows analytical analyses that insider trading is likely to reduce investment from outsiders when outsiders only have the current stock price information and firms do not issue any new shares. Since insiders will recognize their corporate performance precisely and participate in the stock market, outsiders will invest less to avoid unfairness. However, H.E. Leland [1] also shows that insider trading reveals new and useful information, reducing the investment risk of outsiders. This may influence informed traders to choose investment decisions more than uninformed traders. In the real market, institutional traders and foreign traders are major investors and they are considered as informed investors who are able to gather more precise information.

This study also employs the corporate information environment through the level of discretionary accruals and book-to-market ratios because it is deemed to be proxies for investment risk of stock trading. After 
Panel B. Buy and Sell Trading

\begin{tabular}{|c|c|c|c|c|c|c|c|c|c|c|c|c|}
\hline \multirow{2}{*}{$\begin{array}{c}\text { Variables } \\
(N=33,908)\end{array}$} & \multicolumn{5}{|c|}{ Inst_Buyv } & & \multicolumn{6}{|c|}{ Inst_Sellv } \\
\hline & Coeff. & White $t$ & & Coeff. & White $t$ & & Coeff. & White $t$ & & Coeff. & White $t$ & \\
\hline Intercept & -0.028 & -1.1 & & -0.03 & -1.0 & & -0.037 & -1.5 & & -0.035 & -1.5 & \\
\hline ITBUYd & - & - & & -0.02 & -2.9 & **** & - & - & & -0.030 & -2.7 & $* * * *$ \\
\hline ITSELLd & - & - & & 0.06 & 1.9 & ${ }^{*}$ & - & - & & 0.062 & 2.2 & ** \\
\hline ITBUYV & -0.019 & -1.7 & * & -0.01 & -1.0 & & -0.021 & -1.6 & & -0.006 & -0.6 & \\
\hline ITSELLV & 0.007 & 0.2 & & -0.04 & -0.9 & & 0.055 & 1.2 & & 0.003 & 0.1 & \\
\hline $\mathrm{dda}$ & 0.006 & 1.4 & & 0.01 & 1.3 & & 0.005 & 1.3 & & 0.004 & 1.1 & \\
\hline$d b m$ & -0.006 & -1.6 & & -0.01 & -1.6 & & -0.003 & -1.1 & & -0.003 & -1.0 & \\
\hline$I T B \cup Y d^{*} d d a$ & - & - & & 0.02 & 1.4 & & - & - & & 0.035 & 1.8 & * \\
\hline$I T B \cup Y d^{*} d b m$ & - & - & & 0.00 & -0.2 & & - & - & & -0.031 & -1.6 & \\
\hline ITSELLd $d^{*} d d a$ & - & - & & 0.01 & 0.2 & & - & - & & 0.028 & 0.4 & \\
\hline ITSELLd*dbm & - & - & & -0.01 & -0.2 & & - & - & & 0.008 & 0.1 & \\
\hline ITBUYV ${ }^{*} d d a$ & 0.048 & 2.2 & ${ }^{* *}$ & 0.04 & 1.7 & ${ }^{* *}$ & -0.057 & -2.3 & *** & -0.074 & -3.0 & $* * *$ \\
\hline ITBUYV*dbm & 0.015 & 0.8 & & 0.02 & 1.1 & & 0.004 & 0.2 & & 0.017 & 1.2 & \\
\hline ITSELLV ${ }^{*} d d a$ & 0.035 & 0.7 & & 0.02 & 0.3 & & -0.052 & -0.8 & & -0.091 & -1.2 & \\
\hline ITSELLV* $d b m$ & -0.002 & 0.0 & & -0.02 & -0.2 & & 0.027 & 0.4 & & -0.017 & -0.2 & \\
\hline priorv & -0.110 & -3.1 & $* * *$ & -0.11 & -3.1 & *** & 0.181 & 9.0 & $* * *$ & 0.181 & 9.0 & $* * *$ \\
\hline SIZE & 0.001 & 1.0 & & 0.00 & 1.0 & & 0.001 & 1.5 & & 0.001 & 1.4 & \\
\hline$R O A$ & -0.013 & -0.6 & & -0.01 & -0.6 & & -0.003 & -0.1 & & -0.003 & -0.1 & \\
\hline CFO & 0.056 & 2.1 & $* *$ & 0.06 & 2.1 & ${ }^{* *}$ & 0.024 & 1.0 & & 0.024 & 1.0 & \\
\hline$L E V$ & 0.019 & 2.2 & ** & 0.02 & 2.3 & ${ }^{* * *}$ & 0.019 & 2.4 & ** & 0.020 & 2.5 & ** \\
\hline GRW & -0.009 & -1.3 & & -0.01 & -1.3 & & -0.007 & -1.1 & & -0.007 & -1.1 & \\
\hline IND/YEAR & \multicolumn{2}{|c|}{ Included } & & \multicolumn{2}{|c|}{ Included } & & \multicolumn{2}{|c|}{ Included } & & \multicolumn{2}{|c|}{ Included } & \\
\hline F-value & 24.29 & *** & & 19.84 & $* * *$ & & 72.89 & *** & & 59.17 & *** & \\
\hline Adj R square & 0.016 & & & 0.016 & & & 0.048 & & & 0.049 & & \\
\hline Max VIF & 1.86 & & & 2.24 & & & 1.86 & & & 2.24 & & \\
\hline
\end{tabular}

Source: built by the author based on data from KIS-VALUE, FnGuide, DART system.

Notes: '-, "', and · represent significant levels at the 1, 5, and 10 percent levels, respectively.

Definitions of variables are in Table 4 Panel A.

controlling for firm-specific factors, this study provides evidence that the event and the amount of insider trading affect foreign and institutional trading patterns. Furthermore, this study finds that the relation between informed trading and insider trading is more enhanced when firms face a high level of discretionary accruals and a low book-to-market ratio. This study helps policymakers to understand the result of corporate insider trading in firms with earnings management and book-to-market ratio on informed trading patterns. Since informed traders are likely to reflect a bad aspect of insider trading and respond to a good aspect of insider trading, different regulations may be appropriate to firms with a great portion of informed traders.

Following prior literature, this study also provides additional evidence of the relation between insider trading with investment risk and informed trading patterns. This study also helps practitioners in the capital market to understand insider trading related to investment risk. Future studies may examine the effect of various characteristics of investment risk with insider trading and informed trading activities in detail.

\section{REFERENCES}

1. Leland H.E. Insider trading: should it be prohibited? Journal of Political Economy. 1992;100(4):859-887.

2. Seyhun H.N. The Effectiveness of the Insider-Trading Sanctions. Journal of Law and Economics. 1992;35(1):149-182.

3. Medovikov I.S. Can stock analysts predict market risk? New evidence from copula theory. Finance: Theory and Practice. 2019;23(1):38-48. DOI: 10.26794/2587-5671-2019-23-1-38-48

4. Fishman M.J., Hagerty K.M. Insider Trading and the Efficiency of Stock Prices. The RAND Journal of Economics. 1992;23(1):106-122. DOI: 10.2307/2555435

5. Manove M. The Harm from Insider Trading and Informed Speculation. The Quarterly Journal of Economics. 1989;104(4):823-845. DOI: 10.2307/2937869 
6. Aktas N., de Bodt E., Van Oppens H. Legal insider trading and market efficiency. Journal of Banking and Finance. 2008;32:1379-1392. DOI: 10.1016/j.jbankfin.2007.11.003

7. Huddart S., Ke B. Information Asymmetry and Cross-sectional Variation in Insider Trading. Contemporary Accounting Research. 2007;24(1):195-232. DOI: 10.1506/0277-1110-4434-M627

8. Seyhun H.N. Insiders' profits, costs of trading, and market efficiency. Journal of Financial Economics. 1986;16:189-212. DOI: 10.1016/0304-405X(86)90060-7

9. Aboody D., Lev B. Information Asymmetry, R\&D, and Insider Gains. The Journal of Finance. 2000;55(6):27472766. DOI: $10.1111 / 0022-1082.00305$

10. Cohen L., Malloy C., Palmoski L. Decoding inside information. The Journal of Finance. 2012;67(3):1009-1043. DOI: $10.1111 / \mathrm{j} .1540-6261.2012 .01740 . x$

11. Lakonishok J., Lee I. Are insider trades informative? Review of Financial Studies. 2001;14 (1):79-111. DOI: 10.1093/rfs/14.1.79

12. Aboody D., Hughes J.S., Liu J. Earnings quality, insider trading, and the cost of capital. Journal of Accounting Research. 2005;43(5):651-673. DOI: 10.1111/j.1475-679X.2005.00185.x

13. Rozanov K. A. Corporate Governance and Insider Trading. Massachusetts Institute of Technology. Sloan School of Management. Doctoral Thesis. 2008.

14. Jaffe J.F. Special information and insider trading. Journal of Business. 1974;47(3):410-428.

15. Piotroski J.D., Roulstone D. T. Do Insider Trades Reflect Superior Knowledge about Future Cash Flow Realization? Journal of Accounting and Economics. 2005;39:55-81. DOI: 10.1016/j.jacceco.2004.01.003

16. Dechow P., Sloan R., Sweeney A. Detecting earnings management. The Accounting Review. 1995;70(2):193-225.

17. Ali K.S., Mohaisen H.A., Hameed A.A. Joint Audit and the Financial Reporting Quality: Empirical Study on Iraqi Voluntary Joint Audits. International Journal of Innovation, Creativity and Change. 2019;7(8):343-359.

18. Liew J., Vassalou M. Can book-to-market, size and momentum be risk factors that predict economic growth? Journal of Financial Economics. 2000;57:221-245. DOI: 10.1016/S 0304-405X(00)00056-8

19. Culvenor J., Godfrey J.M., Byrne G. Modeling Total Accruals in an International Environment: The Impact of Alternative Measures of PPE. International Accounting, Auditing \& Taxation. 1999;8(2):289-313. DOI: 10.1016/S 1061-9518(99)00017-8

20. Gu F., Li J. The credibility of voluntary disclosure and insider stock transactions. Journal of Accounting Research. 2007;45(4):771-810. DOI: 10.1111/j.1475-679X.2007.00250.x

21. Ke B., Huddart S., Petroni K. What Insiders Know about Future Earnings and How They Use It: Evidence from Insider Trades. Journal of Accounting and Economics. 2003;35:315-346. DOI: 10.1016/S 0165-4101(03)00036-3

22. Acharya V. V., Johnson T. C. Insider trading in credit derivatives. Journal of Financial Economics. 2007;84(1):110-141. DOI: 10.1016/j.jfineco.2006.05.003

23. Smith C.W., Watts R.L. The investment opportunity set and corporate financing, dividend, and compensation policies. Journal of Financial Economics. 1992;32(3):263-292. DOI: 10.1016/0304-405X(92)90029-W

24. White H. A Heteroskedasticity-Consistent Covariance Matrix Estimator and a Direct Test for Heteroskedasticity. Econometrica. 1980;48(4):817-838. DOI: 10.2307/1912934

\section{ABOUT THE AUTHOR / ИНФОРМАЦИЯ ОБ АВТОРЕ}

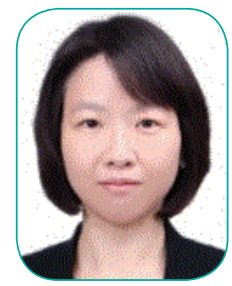

Gyungmin Pyo - Ph.D. Asst. Prof., Department of Taxation, Konyang University, S. Korea Гюнгмин Пё- доктор философии, доцент кафедры налогообложения, Университет Коньянг, Южная Корея https://orcid.org/0000-0001-8029-5627 gmpyo1@gmail.com

Conflicts of Interest Statement: The author has no conflicts of interest to declare. Конфликт интересов: автор заявляет об отсутствии конфликта интересов.

The article was submitted on 12.07.2021; revised on 31.07.2021 and accepted for publication on 17.12.2021. The author read and approved the final version of the manuscript.

Статья поступила в редакцию 12.07.2021; после рецензирования 31.07.2021; принята к публикации 17.12.2021. Автор прочитала и одобрила окончательный вариант рукописи. 